общественными явлениями, что тем самым делает ее ключевой в межличностных отношениях в социуме. Выявлено, что А. Яценко отмечает тесную взаимосвязь культуры и целеполагания и идеалов. По его мнению, культура, будучи социальным явлением, является одной из ключевых форм, в которой человек способен воплощать свои иели и идеалы.

Ключевые слова: В. Иванов, А. Яценко, культура, украинская советская философия, советские мыслители.

V. E. Turenko, PhD, Junior Research Fellow

Taras Shevchenko National University of Kyiv

60, Volodymyrska Street, Kyiv, 01033, Ukraine

N. V. Yarmolitska, PhD, Research Fellow

Taras Shevchenko National University of Kyiv

60, Volodymyrska Street, Kyiv, 01033, Ukraine

\title{
PHILOSOPHICAL EXPLICATION OF CULTURE IN THE WORKS OF V. IVANOV AND A. YATSENKO
}

The article attempts to highlight the understanding of culture in the work of famous Ukrainian Soviet philosophers of the second half of the XX century - Vadym Ivanov and Olexandr Yatsenko. Ukrainian Soviet philosophy of the postwar period is known primarily for research in logic philosophical problems of science, philosophical anthropology, as well as research on the history of national philosophy. At the same time, philosophical and cultural issues seemed to be "in the shadow" of the above studies and actually leveled off in this period of development of Ukrainian philosophical thought. Because of this, there is a need to analyze the legacy of Ukrainian Soviet philosophers, who focused their attention on the philosophical explication of the phenomenon of culture. V. Ivanov and 0 . Yatsenko were among such thinkers.

The thesis is substantiated that the philosophical comprehension of culture, of course, was not in the center of attention of the studied Ukrainian thinkers, however, while developing these or those concepts, they certainly concerned reflections on the cultural phenomenon, which became important for the development of the philosophical tradition in Ukraine. It is proved that for V. Ivanov culture becomes one of the most important factors of human self-realization and self-realization. It is especially important to emphasize that the culture of the Ukrainian Soviet philosopher is very connected with various kinds of social phenomena, thereby making it key in interpersonal relations in society. $V$. Ivanov emphasizes that culture is not a system, but one of the elements of human existence and manifestation of its existence. Thus, culture in the context of human existence determines not only the present, but also the perspective on which human progress is directed in one aspect or another. It was revealed that 0 . Yatsenko notes the close interconnection of culture and goal setting and ideals. In his opinion, culture, being a social phenomenon, is one of the key forms in which a person is able to realize his goals and ideals.

Key words: V. Ivanov, O. Yatsenko, culture, Ukrainian Soviet philosophy, Soviet thinkers.

Удк 17:001.891.32

О. В. Шинкаренко, канд. філос. наук, доц. Київський національний університет імені Тараса Шевченка, вул. Володимирська, 60, м. Київ, 01033, Україна 3864301@gmail.com

\section{ЕТИЧНІ ЕКСПЛІКАЦІї "ВІЗУАЛЬНОГО ПОВОРОТУ" У СУЧАСНІЙ КУЛЬТУРІ}

Стрімке зростання цифрових технологічних можливостей, яке розпочалося з кінця ХX століття $і$ посилилось 8 останні десятиліття, означилося своєрідними змінами в характері і ролі візуалізації в соціокультурному просторі сучасності. Така трансформація викликала не тільки інноваційні зміни в художніх практиках чи їхніх теоретичних інтерпретаціях різними царинами соціогуманітарного знання. До певної міри це стало поштовхом як до фундаментальних змін власне в соціокультурному бутті, так і до трансформацій сучасної людини. Соціально-культурні ефекти повороту культурної практики до домінування візуальної складової викликають нагальну потребу долучення етичних досліджень до наукового дискурсу з проблем візуалізації, візуального образу, візуального сприйняття, їхнього впливу на стан людської готовності щодо нових запитів до поведінки та соціальних взаємин.

Ключові слова: візуальний поворот, візуалізація, візуальний образ, візуальне насилля, етос, естезис, візуальна етика.

Постановка проблеми. Зафріксована в науковому дискурсі своєрідність теперішньої культури, так званий "візуальний поворот" ("іконічний", "піктографічний"), зосередила увагу дослідників на досить широкому колі проблем: від нової інтерпретації "образу", зміни форм і розширення меж когнітивного людського потенціалу до соціально-психологічних ефектів від перенасичення (аж до жорсткої агресивності) різноманіттям візуальних об'єктів за допомогою сучасних технічних засобів у людському існуванні, в урбаністичному середовищі, в буденних практиках, в комунікації. Зрозуміло, що такий масований контакт має вплив як на трансформацію самоідентифрікації людини, так і на характер її поведінки, що не може бути полишене етичною дослідницькою увагою.

Аналіз досліджень і публікацій. Проблематика "візуального повороту" має досить широке висвітлення у роботах як родоначальників дослідження візуалізації сучасної культури (В. Дж. Т. Мітчел, Н. Мірзоєв, Г. Бьоме), так і послідовників щодо акцентуації методологічних поворотів у сучасному соціогуманітарному знанні, зокрема в культурології (Д. Бахман-Медик, І. М. Інішев, В. Савченко, С. Пірогов та ін). Серед різногалузевого обговорення своє місце зайняла і "візуальна етика". Проте етичний аспект тут скоріше пов'язаний із проблемами візуального виробництва (фотожурналістика, візуальна комунікація в 3MI, рекламний контент та ін.) і розглядається в певному прикладному сенсі - в якості моральних аспектів стосунків суб'єктів та об'єктів візуальної комунікації в процесі виробництва та споживання візуальних продуктів (С. Зонтаг, С. Лангер, Е. Коен, Ж. Бодріяр, У. Еко). Однак сучасна візуалізація культури як суттєвий чинник зміни самої людини в процесах виробництва, презентації та споживання візуальних повідомлень актуалізує увагу до етичної складової ії потенціалу як соціокультурного актора у вимірах людяності.

Мета статті - означити етичну проблематизацію наявної ситуації тотальної візуалізації в різних галузях соціокультурного буття, що проявляється в перенасиченні та домінуванні образних елементів, які стають активними самостійними чинниками соціокультурний досвіду, детермінуючи поведінку і стосунки людей.

Виклад основного матеріалу дослідження. Велика "революція зображень", що розпочалась ще у другій половині XIX століття, вже у добу потужного впровадження Інтернету та цифрових можливостей медіасфрери ініціювала особливу дослідницьку увагу кола наук, зокрема культурології. Зростаюча інтенсифікація виробництва і циркуляції образів протягом останніх 
півтора століть спровокувала на порозі XXI століття означення феномену "візуалізації", що стає домінантою сучасної культурної стратегії, як предмета теоретичного розгляду. Якщо на початку теоретичного підходу до проблеми візуалізації її особливості були спричинені бурхливим розвитком фоотографії, кіновиробництвом, технічним тиражуванням традиційних візуальних об'єктів графіки, малюнка, картин, то в подальшому поява дисплея, відео-, телепродукції, активність медіа-сфери розширили розгляд візуалізації. У свій час фрілософри, передчуваючи можливу перспективу візуалізації в культурному бутті ще до сучасного іï "буму", звернулися, наприклад, до проблеми "погляду" як засобу конституювання світу (Ж. П. Сартр), до "видимості" у ставленні людини до дійсності (М. Мерло-Понті), до своєрідності художнього образу в технічному репродукуванні (В. Беньямін). Сьогодні в обговоренні предметів візуальних досліджень - реклама, дизайн, іміджелогія, смисловий простір урбаністичного середовища. Очевидність перенасиченої, медіалізованої, віртуалізованої сучасності в соціокультурному просторі, зростання масштабів нових технологій віртуальної реальності закріпили пріоритет та домінування візуальних образів у порівнянні з літературоцентричним минулим, підважили домінування мови, категоріально-мисленнєвого досвіду. Така зміна пріоритетів зображення (візуального образу) та слова в культурному просторі викликала так званий "віртуальний поворот" в соціогуманітарному знанні ще в 90-х роках XX століття. Попри можливу сьогоднішню тривіалізацію за пройдені десятиліття розгляду, він все ж таки залишається на часі для обговорення в силу вияву різноманітних приводів до роздуму. Зокрема це стосується трансформації предметного фокуса у підходах до візуалізації та розширення галузей і поглиблення дослідницького підходу.

Актуалізація дослідницького інтересу до візуалізації сучасної культури розпочиналась спільними зусиллями теоретиків мистецтвознавства, компаративістики у літературі та історії мистецтв - зокрема, теоретиком мистецтвознавства В. Дж. Т. Мітчелом з Чиказького університету, швейцарським істориком мистецтва Готфрідом Бьоме, американським дослідником медіа і комунікації Ніколасом Мірзоєвим. Проте поглиблення дослідження виявило потребу вивести цей об'єкт дослідження за межі власне мистецьких. Спочатку у фокусі уваги була природа візуального образу та його специфічні модифікації під впливом нових технологічних можливостей. Проте потужний сплеск візуальної образності за останні десятиліття в соціокультурному бутті призвів до розгортання дослідження в таких актуальних напрямках, як історичні, фрілософські та антропологічні студії образів, візуальна соціологія, візуальне медіаведення, транскультурна наука про культуру образів та візуальні дослідження (visual studies) [3, с. 395]. Заявлене дослідницьке поле культури крізь фокус домінанти візуалізації, все більше набуваючи масштабу "everything studies" (Сенді Айзенштад), формує порядок денний і сучасної культурології. "Розширення історії мистецтв до культурологічної перспективи, таким чином, дозволяє переадресувати увагу на внесок подібної рефлексії в переспрямування наук про культуру" [3, с. 396]. У культурологічній перспективі питання візуалізації загострювалось ще й потребою визначення, наскільки і в чому візуальність 3 ії̈ наявною надлишковістю образів $є$ специфічною характеристикою сучасності. Адже зрозуміло, що візуальні образи існували завжди в будь-якій культурній практиці. Проте чим може бути щодо сутності культури як такої їхня теперішня надмірність?
Викликаний новими проявами образності у культурній практиці дослідницький інтерес доповнюється і потребами нового методологічного озброєння задля їх осягнення. У процесі свого формування і розвитку "візуальний поворот" вже рясніє різноманіттям підходів та концептуальних позицій. Так, у колі досліджень різняться концептуальні заявки про "іконічний" (формулу "iconic turn" ввів Готфрід Бьоме у 1994 р.), "пікторальний" ("pictorial turn" - запропонував Томас Мітчел у 1992 р.), "візуальний" ("visual turn" - К. Закс-Гомбах), ілюстративний (Ф. Фельман) повороти, "visual studies" теоретична стратегія в рамках британських "культурних досліджень" [7]. Таке різноманіття означень у пошуках відповідного опису ("оптики") - це і процес становлення дослідницького простору. Але наявність диференційних протилежних дисциплінарних компетенцій $€$ реакцією на практичні виклики (трансформації самої реальності), що спричинені велетенським розширенням за допомогою медіа (кіно, відео, цифрова візуалізація) візуального сприйняття культури.

Дослідницькі підходи розвиваються від дослідження походження і природи візуального образу, характеру зображень, способів інтерпретації візуальних образів до особливостей візуального сприйняття, специфіки переживання візуального, його сугестивних ефектів та можливостей візуальної комунікації, ідеологічного та політичного навантаження образів, їхнього впливу на людську поведінку та соціальні зміни тощо. У такому широкому діапазоні мають своє місце і такі класичні дослідницькі дисципліни, як естетика та етика. Оскільки те навантаження, що несуть візуальні образи, тим більше вже не лише в якості засобів репрезентації інформації, а як власне інформація, викликає трансформацію механізмів та способів трансляції культурних універсалій, з одного боку, та їхній вплив на мислення та поведінку людей, з другого.

В німецькомовних дослідженнях континентальної думки "іконічного повороту" (Г. Бьоме, Х. Бреденкамп, Г. Бельтинг, М. Кемп, М. Вранке) обговорюються онтологічні та епістемологічні питання, пов'язані з проблематикою образності: внутрішня структура образу, його зв'язок із матеріальним носієм, потенціал образу як ресурсу пізнання, його приналежність як матеріальній культурі, так і сфері смислових презентацій. Здавалось би, така постановка проблеми співпадає з попередньою семіотичною і герменевтичною традиціями (родоначальник цього підходу Готфрід Бьоме здійснив свою докторську дисертацію під керівництвом Ганса Гадамера). Але звичного для семіотичної традиції розуміння візуального об'єкта (образу) як "системи знаків", пошуку сенсів у ньому виявляється недостатнім. Інновацією "іконічного" повороту став заклик до трансформації розмислів про образи в дослідження мислення за допомогою образів. Лише лінгвістичний аналіз вже не вичерпує площини смислів, на якій розгортаються основні культурні процеси. Потрібне розширення аналізу текстуальності до аналізу простору образів через "повернення до зображення". Прихильники "іконічного" повороту наголошують, що семіотика образів $є$ обмеженою через свій підхід за аналогією з мовою та використання розшифрування та декодування. Проте вона не враховує потенціал емоційного впливу образів, не звертає увагу на спосіб, яким образ діє завдяки своїй магії на глядача. "Перш за все, зображення афектують. Це означає, що образи не можуть бути просто прочитаними, вони мають бути пережиті (experienced)" [1, с. 243].

Увага вчених спрямовується на реальну присутність образу в культурі як наявності, що взаємодіє 3 людиною. В центрі уваги "об'єктивна царина, що скла- 
дається 3 речей, доступних нашому погляду чи існування яких мотивоване їхньою здатністю бути видимими. Речей, що мають специфрічну візуальність чи візуальну якість, що адресуються суспільству, яке взаємодіє навколо них" [2, с. 217].

У північноамериканських та британських студіях про візуалізацію культури фокусом уваги стають завуальовані в образі смисли здебільшого з маніпулятивним політичним та ідеологічним навантаженням. Але навіть така поверхова схожість з семіотичним аналізом не зашкоджує головній відмінності теперішнього підходу до розгляду специфріки образу як автономного явища. Все більше наголошується не стільки на соціальному конструюванні об'єктів як візуального поля культури, скільки на візуальному конструюванні соціального поля як власне "пікторального повороту" (Т. Мітчел). Візуальна культура - "це не частина повсякденного життя це саме повсякденне життя" (Н. Мірзоєв).

Така акцентуація на розумінні візуального образу як, "можливо, єдиного об'єкта, що в процесі свого сприйняття не тільки споживає "семантичні ресурси", ссормовані в інших царинах, наприклад в мовній комунікації чи тілесних практиках, ...являє собою продовження позаобразного досвіду, а з іншого боку, перериває його плин, привносячи в нього зміст..." [5, с. 185]. "Тут образ вже не стільки являє собою "репрезентацію" чи "відображення", не є лише інструментом чи комунікативним посередником, скільки виступає в якості середовища чи "насиченого розчину" як інтерференція матеріального та змістовного" [5, с. 197].

Продуктивність такого розуміння потенціалу сучасної візуальної образності особливо наочно засвідчується сучасними дослідженнями урбаністики, в яких піднімаються питання впливу міського середовища, образу міста, образів різних життєвих просторів на людську поведінку. Різні режими бачення, сприйняття топосу, переживання "духу місця" - це розуміння їх як простору символічних "тактик" поведінки (М. де Серто). Різноманіття візуальних об'єктів оточує людину в їі урбаністичному середовищі з часто-густо агресивними для сприйняття подразниками: в нав'язливій комерціалізації, де через активну візуалізацію досягаються успіхи в конкуренції та формується потрібний споживач; в оглядовості публічного життя як способу бути успішним. Візуальність сьогодні визначає ставлення людини до себе, іiї дії, спосіб осягнення дійсності, самовираження індивіда, детермінуючи культурну ідентичність, що в кінцевому рахунку визначає соціальний світ.

Активність візуалізації в специфріці сучасного продукування і поширення зображувальності як чинника соціально-культурного конструювання загострює проблему ії впливу на характер світу та трансформації самої людини. Візуальні дослідження в розвиткові "візуального повороту" охоплюють весь обшир індивідуальних соціальних відносин, де присутній візуальний елемент. Сучасна людина щільно оточена візуальними образами, і через них вона звертається до світу, сприймає повсякдення. Візуальне проникає в людську свідомість автоматично, здебільшого у формі "оптичної ілюзії" із зміщенням межі "реального-уявного". При сприйнятті образу людина не тільки розшифровує певний зашифрований зміст. Сам конструктивізм візуального образу є більш захованим від глядача і здається об'єктивованим сповіщанням самого світу, породжуючи довіру споживачів до візуальних артефактів як свідчень самої реальності. В забезпеченій теперішніми технічними можливостями подачі візуальних образів людина невільно підпадає під владу образу як самостійної реальності, часто-густо не усвідомлюючи певну можливість його виступати симу- лякром, тобто бути репрезентацією того, чого насправді не існує (Ж. Бодріяр). Останній процвітає в процесі переорієнтації постмодерної культури на чуттєвоестетичний, "видовищний" спосіб сприйняття світу, де на противагу морально-духовному перевага перебуває на боці почуттєвого й афективного, що живиться посиленим продукуванням візуалізації задля подолання нудьги повсякдення. "Образ завжди несе з собою загрозу заполонити уяву, заколисати, чи, навпаки, відволікати і збуджувати - наслідком чого в обох випадках $є$ послаблення критичної думки, яка передбачає здатність до концентрації, абстрактного мислення, схоплення негативного" [4, с. 131]. Під тиском візуального насилля людина не тільки може втрачати адекватне сприйняття реальності, перетворюватися на вельми доступний об'єкт маніпуляції, а й силою імпліцитного впливу образу, який формує мислення, спрямованість ії̈ емоцій, навіть стан пам'яті, впливає на образ/стан самої реальності.

Така залежність загострює потребу принести в дослідження візуалізації сучасної культури ще один ракурс розгляду - етичний. Адже оборотною стороною сьогоднішнього превалювання візуального в просторі культури, який в більшості під тиском ринку стає засобом "економічних стратегій", тиражуючи масовий продукт, стає дефіцит та маргіналізація етичної зорієнтованості на користь домінування естетичного. Такий ухил прислуговує закріпленню розповсюдженої у сучасного загалу етичної індиферентності, яка в механізмах самовизначення індивіда обертається соціальною безпорадністю та інфантилізмом.

Сьогодні "диктатура ока" (Т. Мітчел) як наслідок засилля візуальних медіа, які домінують над текстуальністю і письмом, мовленням, може виглядати в певній мірі загрозою атрофії всіх перцептивних можливостей людини, окрім зору. Однак щоб не впасти в однобокість моралізування, варто ураховувати і відкритий у візуальних дослідженнях евристичний потенціал візуальності як нового, відмінного від категоріально-мисленнєвого, досвіду людини. Думка, що візуалізація відображує ту стадію розвитку культури, коли набувається здатність транслювати смисли в концентрованій, легко пізнаваній формі, створюючи цілісні та пластичні картини реальності, долаючи мовні, соціальні, культурні бар'єри, посвоєму стимулюючи уяву та творчі здібності, правомірна в баченні того, що "органічне залучення зображень в систему культури на всіх етапах її еволюції, їх пластичність, багатство символічної наповненості і багатошаровість засвідчують пізнавальну цінність візуальних образів" [8]. Тому "сама по собі візуалізація культури не несе загрози культурної та інтелектуальної деградації: лише окремі, найбільш "масовізовані" ії прояви, а також пов'язані з ними технології конструювання і репрезентації візуальних образів можуть сприяти примітивізації сприйняття та мислення" [8].

Звідси проблемність сучасної візуалізації, викликана не стільки масштабністю чи агресивністю наступу візуальних об'єктів в щоденності людського буття, скільки мірою духовно-практичної готовності людини до продуктивної взаємодії із такою реальністю сучасного світу.

У сьогоднішніх обговореннях своєрідності та змін у характері сучасної культурної практики все частіше піднімається проблема співвідношення етосу та естезису в людському сприйнятті та переживанні світу. Бачиться, що справа вирішення негативних наслідків візуалізації полягає в налаштуванні відповідності візуальних практик відомому ще з античних часів принципу "калокагатії" - універсальної невіддільності етосу та естезису. Введення цих понять в сьогоднішній дискурс передбачає їх більш розширене розуміння, ніж прив'язку до власне 
моралі, етики чи естетики. Тим більше що, стосовно останніх, по сьогоднішній день довільність у їх трактуванні та використанні не сприяє продуктивному висвітленню наявних проблем. Якщо у випадку розгляду взаємин етики та естетики пропозиція їхньої співмірності в силу радикальної автономії культурних форм попередніх часів все ж таки виходила з традиційного "або - або" (С. Кіркегор), то продуктивність теперішнього розуміння, що продукується самою практикою постмодерної культури, означеною характером "де-диференціації" (С. Леш), базується не просто на урахуванні їхнього бажаного поєднання, а на їхній органічній цілісності, принциповій неподільності. Як стверджує Бенно Хюбнер, за таким баченням, "етос", на відміну від моралі і навіть етики, - це фріксація "відношення (дії, почуття у відношенні) до того, що для Я являє Цінність, екзистенційну Цінність", це "якість ставлення Я до Іншого", в якому люди "почувають себе ек-зистенційно зобов'язаними". Це, на думку фрілософа, стверджує витокову укоріненість етичного в естетичному, це етос як відповідь на потребу людини трансцендувати своє Я, долаючи психічну пустоту, психічне ніщо, anima morte, свою зайвість, даремність, що продукуються у світі, якщо допускається панування лише естетики "зачарування" (В. Вельш) чи "інтенсивності" (Ж. Ліотар). Більше того, через відсутність будь-якого етосу, чи скоріше через його повну естетизацію, з опорою тільки на почуття задля звільнення від нудьги, отримана свобода супроводжується повним крахом відповідальності [9]. Сьогоднішні обставини надлишку естетичного, які посилені можливостями сучасних медіа безперервно тиражувати та в безмежних кількостях прирощувати візуальні образи, прискорюють цей процес, посилюють деструктивні для соціального буття ефекти. Сьогоденне питання етосу зразу ж проявляється і питанням естезису як своєї оборотної сторони.

Розгляд естезису, запропонований Мішелем Маффесолі у зв'язку із новими тенденціями у характері сучасної соціальності як вияві кризи попередніх інституцій структурування й упорядкування суспільства, теж проявляє означену цілісність з етосом. Термін "естезис" (від грец. відчуття, почуття), запропонований М. Маффесолі для опису специфічного досвідомого світо- і самовідчуття, $€$ виявом постмодерної соціальності, яка на відміну від суспільства у традиційному (модерному) розумінні репрезентована "солідарністю спільних почуттів", "колективною чуттєвістю": "те, що ми бачимо навколо, або те, що стає нам ближчим через образи, займає усіх нас, створюючи колективні емоції. Механізм, про який йде мова, має неабияке значення, адже повертає нас до холістичного (глобального) принципу... що ми беремо участь або рівняємось на загальний етос", це - "колективна чуттєвість, що виникає з форми естетичного, приводить до етичного зв'язку" [6, с. 55]. Філософ вбачає тут "етику естетики", виголошуючи об'єднуючий потенціал пережитих емоцій та спорідненість смаків нових спільнот постмодерної доби - "нових племен", що проявляють ламку старих форм соціальності.

Висновок. Отже, в засновках культури, яка стрімко розвинула за допомогою сучасної інформатизації та технізації міць візуальної репрезентації, етичні смисли сприяють збереженню культурно-значимому потенціалу візуальних об'єктів як репрезентованого естезису. За умов такої збалансованості останній сприяє пробудженню і культивуванню належного рівня співчуття як умови протидії "адіафоризації" реального життя, наявній сьогодні "взаємності морального збайдужіння" (3. Бауман). Хоч означена цілісність етосу та естезису в більшій мірі носить сьогодні латентний характер, але ії̈ урахування стимулює імплементацію етичної проблематики щодо дослідження соціокультурної практики, що радикально повернула до візуальності як своєї домінантної характеристики. Ураховуючи, що в більшій мірі ця візуальність через панування нових технологій медійності $€$ ще й обтяженою втратою безпосередності людського контакту, атомізованістю, то першочерговість такої тематизації бачиться не лише даниною інтелектуальній традиції, а й практичним запитом. Нагальна потреба такого дослідницького підходу є очевидною в сучасних етичних теоретичних розвідках, де на порядку денному $є$ постановка під питання притаманної практиці Модерну віри в можливість неамбівалентного, неапоретичного етичного кодексу (3. Бауман) та розуміння, що серед загальних умов моральності як цілісності своє місце займає емоційна, почуттєва готовність до переживання взаємності 3 Іншим у відкритості події спільнобуття "обличчя-до-обличчя" (зокрема і візуальній "очі-в-очі").

Так, для власне "візуального повороту" як тренду сучасних культурологічних досліджень етична спрямованість проглядається в тенденції предметного оформлення візуальної етики як одного із напрямків візуальних досліджень. Однак її місія бачиться не тільки в якості прикладного забезпечення механізму регулювання певної культурної практики візуального виробництва (фото-, відеожурналістика, етика реклами, етика Інтернету), а в широкому розумінні антропологічного запиту як пошуку співмірного сучасним культурним реаліям соціального діяча, а не загубленого в гонитві за насолодою в "цивілізації образу" споживача.

\section{СПИСОК ВИКОРИСТАНИХ ДЖЕРЕЛ}

1. Аветисян А. І. Мапа візуальних студій: основні принципи досліджень / А. І. Аветисян А. І. // Гілея: науковий вісник. - 2016. - Вип. 112. C. 241-244.

2. Баль М. Визуальный эссенциализм и объект визуальных исследований / М. Баль // Логос. - 2012. - № 1 [85]. - С. 212-249.

3. Бахман-Медик Дорис. Культурные повороты. Новые ориентиры в науках о культуре / Д. Бахман-Медик [пер. с нем.] - М.: Новое литературное обозрение, 2017. - 504 с.

4. Брюховецька О. В. Візуальний поворот у культурі і культурології / О. В. Брюховецька // Культурологія: Могилянська школа: колективна монографія / наук. ред. та упоряд. М. А. Собуцький, Д. О. Король, Ю. В. Джулай. - К.: Олег Філюк, 2018. - С. 130-165. - Режим доступу: http://ekmair.ukma.edu.ua/handle/123456789/15232

5. Инишев И. "Иконический поворот" в теориях культуры и общества / И. Инишев // Логос. - 2012. - № 1. - С. 184-211.

6. Маффресолі Мішель. Час племен. Занепад індивідуалізму у постмодерному суспільстві / М. Маффесолі - К.: Вид. дім "КиєвоМогилянська Академія, 2018. - 264 с.

7. Реутов А. С. Визуальные исследования современной культуры: феноменологический аспект. - 2018. - [Електронний ресурс] / А. С. Реутов - Режим доступу: https://www.mininuniver.ru

8. Стризое А. Л., Храпова В. А. Вербальное и визуальное в культуре: иерархия или дополнительность? - 2018. - [Електронний ресурс] / А. Л. Стризое, В. А. Храпова. - Режим доступу: http://vphil.ru/index.php? option=com_content\&task=view\&id $=2001 \&$ ltemid $=52$

9. Хюбнер Бенно. Произвольный этос и принудительность эстетики [Електронний ресурс] / Б. Хюбнер. - Режим доступу: https://royallib.com/ book/benno_hyubner/proizvolniy_etos_i_prinuditelnost_estetiki.html

\section{REFERENCES:}

1. Avetisyan, A. I. (2016). Mapa vizualnih studij: osnovni principi doslidzhen [Map of visual studies: basic principles of research]. Gileya: naukovij visnik, 112, 241-244.

2. Bal, M. (2012). Vizualnyj essencializm i obekt vizualnyh issledovanij [Visual Essentialism and the Object of Visual Research]. Logos, № 1 [85], 212-249.

3. Bahman-Medik, Doris. (2017). Kulturnye povoroty. Novye orientiry v naukah o kulture [Cultural turns. New landmarks in the cultural sciences]. Moskow, Novoe literaturnoe obozrenie.

4. Bryuhovecka, O. V. (2018). Vizualnij povorot u kulturi i kulturologiyi [Visual turn in culture and culturology]. In Kulturologiya: Mogilyanska shkola: kolektivna monografiya. Kyiv, Oleg Filyuk. Retrieved from http://ekmair.ukma.edu.ua/handle/123456789/15232

5. Inishev, I. (2012). "Ikonicheskij povorot" v teoriyah kuultury i obshestva ["Iconic Turn" in theories of culture and society]. Logos, №1, 184-211. 
6. Maffesoli, Mishel. (2018). Chas plemen. Zanepad individualizmu u postmodernomu suspilstvi [Tribal time. The decline of individualism in postmodern society]. Kyiv Vid. dim "Kiyevo-Mogilyanska Akademiya".

7. Reutov, A. S. (2018). Vizualnye issledovaniya sovremennoj kultury: fenomenologicheskij aspekt [Tribal time. The decline of individualism in postmodern society]. Retrieved from https://www.mininuniver.ru.

8. Strizoe, A. L., Hrapova, V. A. (2018). Verbalnoe i vizualnoe v kulture: ierarhiya ili dopolnitelnost? [Verbal and visual in culture: hierarchy or complementarity?] Retrieved from http://vphil.ru/index.php?option= com_content\&task=view\&id=2001\&Itemid=52

9. Hyubner, Benno. Proizvolnyj etos i prinuditelnost estetiki [Arbitrary ethos and compulsory aesthetics]. Retrieved from https://royallib.com/ book/benno_hyubner/proizvolniy_etos_i_prinuditelnost_estetiki.html

Надійшла до редколегії 02.12.19

Е. В. Шинкаренко, канд. филос. наук, доц.

Киевский национальный университет имени Тараса Шевченко,

ул. Владимирская, 60, г. Киев, 01033, Украина

\section{ЭТИЧЕСКИЕ ЭКСПЛИКАЦИИ "ВИЗУАЛЬНОГО ПОВОРОТА" В СОВРЕМЕННОЙ КУЛЬТУРЕ}

Стремительный рост цифровых технологических возможностей, который начался с конца ХX века и усилился в последние десятилетия, обозначился своеобразными изменениями в характере и роли визуализации в социокультурном пространстве современности. Такая трансформация вызвала не только инновационные изменения в художественных практиках или их теоретических интерпретациях различными областями социогуманитарного знания. В известной степени это стало толчком как к фундаментальным изменениям в собственно социокультурном бытии, так и к трансформациям современного человека. Социально-культурные эффекты визуального поворота культурной практики с доминированием визуальных объектов в различных сферах жизнедеятельности человека вызывают настоятельную необходимость добавления этических исследований в научный дискурс по проблемам визуализации, визуального образа, визуального восприятия, их влияния на состояние человеческой готовности в связи с новыми запросами к характеру поведения индивида и социальных взачмоотношений. Такая задача видится в обращении к новому прочтению проблемы соотношения этоса и эстетиза.

Ключевые слова: визуальный поворот, визуализация, визуальный образ, визуальное насилие, этос, эстезис, визуальна этика.

O. B. Shynkarenko, PhD, Assosiate Professor

Taras Shevchenko National University of Kyiv,

60, Volodymyrska Street, Kyiv, 01033, Ukraine

\section{ETHICAL EXPLICATIONS OF "VISUAL TURN" IN CONTEMPORARY CULTURE}

The article is devoted to the coverage of possible ethical conclusions from the stated "visual turn" in the study of contemporary transformations of culture. The rapid growth of digital technological capabilities, which began at the end of the twentieth century and intensified in recent decades, has been characterized by changes in the nature and role of visualization in the socio-cultural space of the present. The sociocultural effects of the reversal of cultural practice on the dominance of the visual component cause the urgent need to integrate ethical research into the scientific discourse on visualization, visual image, visual perception, and their influence on the state of human readiness for new behavioral requests and social relationships.

Among the multi-sectoral discussions, "visual ethics" also took its place. However, the ethical aspect here is more related to the problems of regulating the relations that arise in the process of visual production (photojournalism, visual communication in the media, advertising content, etc.). It is considered in a certain applied aspect - as moral aspects of the relations of subjects and visual communication in the process of production and consumption of visual products. At the same time, visual studies tend to analyze imagistic representations while ignoring many of the ethical dimensions involved. The study of sociocultural practice, which has radically returned to the visual as its dominant characteristic and yet burdened by the dominance of new technologies of mediation by the loss of the directness of human contact, atomization, require a broader anthropological understanding of the formation of man as an active social actor. Such a task is seen in addressing the problem of a new reading of the problem of the correlation of ethos and aesthesis. For the "visual turn" as a trend of modern cultural studies, ethical orientation is seen in the trend of subject design of visual ethics as one of the areas of visual research.

Key words: visual rotation, visualization, visual image, visual violence, ethos, esthesis, visual ethics. 